\title{
Reactions of harbor porpoises Phocoena phocoena and herring Clupea harengus to acoustic alarms
}

\author{
Boris M. Culik ${ }^{1, *}$, Sven Koschinski ${ }^{1}$, Nick Tregenza ${ }^{2}$, Graeme M. Ellis ${ }^{3}$ \\ ${ }^{1}$ Marine Zoologie, Institut für Meereskunde, Düsternbrooker Weg 20, 24105 Kiel, Germany \\ ${ }^{2}$ Institute of Marine Studies, University of Plymouth, Drake Circus, Plymouth PL4 8AA, United Kingdom \\ ${ }^{3}$ Department of Fisheries and Oceans, Pacific Biological Station, Nanaimo, British Columbia V9R 5K6, Canada
}

\begin{abstract}
Small cetaceans are susceptible to incidental mortality in the various forms of gillnet fisheries throughout their range. Research conducted since 1994 has shown that acoustic alarms (pingers) emitting high-frequency pulsed sounds effectively reduce the number of harbor porpoise Phocoena phocoena casualties in sink gillnets. However, the mechanisms behind the effects of pingers were still not understood. Until now, advantages and risks associated with their widespread use could not be evaluated. Here we present the results of 2 field experiments: (1) theodolite-tracking of harbor porpoises exposed to a single PICE-pinger in Clayoquot Sound, Vancouver Island, Canada and (2) herring Clupea harengus capture rates in surface gillnets equipped with and without acoustic alarms (Dukane Netmark 1000, Lien, PICE) in the Baltic Sea herring fishery at Rügen Island, Germany. Our results show that harbor porpoises do not seem to react to an experimental net in their foraging area $(\mathrm{n}=172$ groups, median group size $=2$ porpoises). Porpoise distance from the mid-point of the net was distributed around a median of only $150 \mathrm{~m}$ (range 4 to $987 \mathrm{~m}$ ). A net equipped with an acoustic alarm, however, was avoided ( $\mathrm{n}=44$ groups) within audible range (distance distribution median $=530 \mathrm{~m}$, range 130 to $1140 \mathrm{~m}$ ). The porpoises were thus effectively excluded from the ensonified area. Herring, one of the main prey species of harbor porpoises, were not affected by the acoustic alarms tested $(\mathrm{n}=25407$ fish captured). The advantages and risks of using acoustic alarms to mitigate by-catch are discussed.
\end{abstract}

KEY WORDS: Harbor porpoise $\cdot$ By-catch $\cdot$ Mortality $\cdot$ Theodolite-tracking $\cdot$ Acoustic alarms $\cdot$ Pinger Gillnets · Noise

\section{INTRODUCTION}

Small cetaceans are susceptible to incidental catches and mortality in various forms of gillnet fisheries throughout their range. Fisheries by-catch poses high risks to the endangered vaquitas Phocoena sinus in the Gulf of California (Rochas-Bracho \& Taylor 1999). Incidental takes of the closely related harbor porpoise $P$ hocoena phocoena in the Gulf of Maine, Bay of Fundy, and the North, Celtic and Baltic Seas may exceed sustainable levels and potentially threaten these local

\footnotetext{
*E-mail: bculik@ifm.uni-kiel.de
}

stocks (Tregenza et al. 1997, Trippel et al. 1999, Vinther 1999, further details see http://www.ascobans.org/). In a recent paper, Kastelein et al. (2000a) were able to show that the reason for harbor porpoise entanglement in gillnets is their inability to detect monofilament nets from distances greater than 3 to $6 \mathrm{~m}$.

Research conducted since 1994 (Lien \& Hood 1994) has shown that acoustic alarms emitting high-frequency pulsed sounds effectively reduce the number of harbor porpoise casualties in sink gillnets (Kraus et al. 1997, Trippel et al. 1999). This has led to their compulsory use in some fisheries (Trippel et al. 1999, Finn Larsen pers. comm.). To date, most studies of the effectiveness or mechanisms of acoustic alarms in reducing 
small cetacean by-catch have been conducted either in fisheries (e.g. Trippel et al. 1999), which returns low sample sizes from animals caught in nets, or in enclosures (e.g. Kastelein et al. 2000b), which yields data that have to be confirmed in the wild. Consequently, the mechanisms behind the effects of such alarms were, until now, poorly understood (Kraus 1999), and advantages and risks associated with their widespread use could not be properly evaluated.

Here we present the results of 2 field experiments which demonstrate that harbor porpoises avoid acoustic alarms, thereby becoming effectively excluded from ensonified areas, whereas herring Clupea harengus, one of their main prey species (Kraus et al. 1997), are not affected.

\section{MATERIAL AND METHODS}

Theodolite-tracking of harbor porpoises. From 25 June to 16 July 1999, we conducted behavioural observations on harbor porpoises in Fortune Channel $\left(49^{\circ} 11^{\prime} \mathrm{N}, 125^{\circ} 46.5^{\prime} \mathrm{W}\right)$, Clayoquot Sound, Vancouver Island, Canada, using an electronic data-logging theodolite (Geodimeter 610, Canada Ltd). The fjordlike area surrounded by mountains offered calm conditions at 0 Beaufort for 3 to $8 \mathrm{~h} \mathrm{~d}^{-1}$, i.e. perfect conditions to accurately track the positions of surfacing harbor porpoises (Koschinski \& Culik 1997). Boat traffic in the area was very rare, with a maximum of 3 to 5 small outboard powered boats $\mathrm{d}^{-1}$.

The theodolite was positioned on a cliff ca $13 \mathrm{~m}$ above sea level and used to obtain horizontal and vertical angles as well as the time and incremental number of each surfacing of the harbor porpoise groups. 'Footprints', i.e. ripple marks where the animals had broken the surface, were visible in most cases even after harbor porpoises had dived again. In porpoise groups we tracked the leading animal whenever possible. Theodolite elevation above sea level (higher high water mark in Clayoquot Sound is $4.1 \mathrm{~m}$ above lower low water mark, large tides) was obtained every 30 min by measuring the angle of the water surface at a sounding line attached on the opposite shore of the channel. The distance to a reflector attached to the sounding line was measured with the built-in laser of the theodolite to within $1 \mathrm{~mm}$ of accuracy. Theodolite elevation above sea level was linearly interpolated between recording intervals. The sounding line also served as reference point (angle $0^{\circ}$ ) for measurements of the horizontal angle of harbor porpoise sightings. An accurate position of surfacing animals could readily be calculated from theodolite data of elevation above sea level and horizontal and vertical angles of surfacings using simple trigonometric equations. Instrument accuracy suggests that range error of sightings was less than $3 \mathrm{~m}$ at maximum range, while azimuth error was less than $50 \mathrm{~cm}$. The coast line and the position of the float line were also recorded using this procedure.

A surface gillnet was simulated in a non-lethal form using a float line (10 mm polypropylene line, $65 \mathrm{~m}$ long, with ellipsoid foam floats spaced every $50 \mathrm{~cm}$ ) and placed perpendicular to the main swimming direction of harbor porpoises in an area of high animal density. We attached $10 \mathrm{~m}$ long, monofilament lines $(0.5 \mathrm{~mm}$ diameter), spaced $0.5 \mathrm{~m}$ apart and weighted at their distal end, to the float line in order to simulate a gillnet with dimensions of $65 \times 10 \mathrm{~m}$ (cf. Koschinski \& Culik 1997). No footrope was attached to the weighted lines.

In order to detect the presence of harbor porpoises day-round, we positioned a detector $1 \mathrm{~m}$ below the mid-point of the float line. The detector $(46 \mathrm{~cm}$ long by $12.5 \mathrm{~cm}$ diameter) is self-contained and automatically counts porpoise clicks in $2 \mathrm{~s}$ intervals when the device is adjusted to $132 \mathrm{kHz}$ and 50 to $500 \mu \mathrm{s}$ (for details see http://www.chelonia.demon.co.uk/PODhome.html).

Between 8 and 12 July we continuously operated 1 acoustic alarm (PICE pinger, Loughborough University, UK) at a depth of $30 \mathrm{~cm}$ below the surface and at the mid-point of the float line. The alarm generated 8 different wide-band swept frequency signals between 20 and $160 \mathrm{kHz}$ at a maximum source level of $145 \mathrm{~dB}$ (re $1 \mu \mathrm{Pa}$ at $1 \mathrm{~m}$ ) for $300 \mathrm{~ms}$ at random intervals of 5 to $30 \mathrm{~s}$. This signal was well within the hearing spectrum of harbor porpoises (Andersen 1970). The range of audibility, $R$, of the alarm can be approximated using $\mathrm{Au}$ (1993).

$$
\mathrm{DT}=\mathrm{SL}-(20 \cdot \log R+a \cdot R)
$$

where DT is the detection level of harbor porpoises (Andersen 1970), SL is the source level of the device and $a$ is the acoustic absorption coefficient in seawater.

We measured source levels of the PICE pinger at the Wehrtechnische Dienststelle 71 of the German Navy in Plön. The pinger was submersed at $5 \mathrm{~m}$ depth in Lake Plön at $1 \mathrm{~m}$ distance from a calibrated hydrophone. Source levels were measured over 50 sweeps emitted from the pinger in the frequency range between 50 and $100 \mathrm{kHz}$. Values in Table 1 show minima and maxima of highest measured source levels of single sweeps. From this we estimated the hearing range of the PICE pinger for harbor porpoises. For frequencies between 55 and $100 \mathrm{kHz}$, this yields a range of 50 to $1900 \mathrm{~m}$ at which harbor porpoises can detect PICE pinger sounds (Table 1).

Behavioural observations were conducted in 3 blocks. Harbor porpoises were tracked: (1) between 3 and 8 July for a total of $26.5 \mathrm{~h}$ to monitor their behav- 
Table 1. Estimated hearing ranges $(\mathrm{m})$ for harbor porpoises Phocoena phocoena at various frequencies emitted by PICE pingers. Pinger source levels were measured, absorption coefficients and detection threshold were taken from $\mathrm{Au}$ (1993). For details, see text

\begin{tabular}{|c|c|c|c|c|c|c|}
\hline \multirow{2}{*}{$\begin{array}{l}\text { Frequency } \\
\text { (kHz) }\end{array}$} & \multicolumn{2}{|c|}{ Source level (dB) } & \multirow{2}{*}{$\begin{array}{l}\text { Absorbtion } \\
\left(\mathrm{dB} \mathrm{m}^{-1}\right)\end{array}$} & \multirow{2}{*}{$\begin{array}{c}\text { Detection level } \\
(\mathrm{dB})\end{array}$} & \multicolumn{2}{|c|}{ Hearing range $(\mathrm{m})$} \\
\hline & Min. & Max. & & & Min. & Max. \\
\hline 55 & 137 & 145 & 0.013 & 55 & 1400 & 1900 \\
\hline 83 & 133 & 138 & 0.02 & 57 & 850 & 1050 \\
\hline 100 & 95 & 120 & 0.03 & 60 & 50 & 330 \\
\hline
\end{tabular}

median of 102 clicks h$^{-1}$ (range 0 to $1762, \mathrm{n}=99 \mathrm{~h})$. Swimming speed of the porpoises as determined from positional information was $0.52 \mathrm{~m}$ $\mathrm{s}^{-1}$ (median; min. $0 \mathrm{~m} \mathrm{~s}^{-1}$, max. $6.2 \mathrm{~m}$ $\left.\mathrm{s}^{-1}, \mathrm{n}=2141\right)$.

While the acoustic alarm was in use, we recorded 987 positions of 44 harbor porpoise groups (1 to 5 individuals, median $=2$ ). As shown in Fig. 1B, pinger operation resulted in an exclusion zone around

iour to the artificial net, (2) between 8 and 12 July for a total of $21 \mathrm{~h}$ to record their reaction to pinger operation, and (3) between 13 and 14 July for a total of $7 \mathrm{~h}$ to study the behaviour of the porpoises towards the artificial net after removal of the acoustic deterrent.

Test of pingers in the herring fishery. On 22 and 23 April and between 2 and 5 May 1998, we participated in commercial herring fisheries in the Baltic Sea near the island of Rügen, Germany. Water depth in the area was approx. $7 \mathrm{~m}$. Weather conditions during fishing were fair, with wind speeds around 3 to 4 Beaufort and not exceeding 6 Beaufort. Net strings $(n=6)$ consisted of surface gillnets composed of between 7 and 5 nets (each 26 or $44 \mathrm{~m}$ long), respectively, with a mesh width of 26 to $27 \mathrm{~mm}$, and a net height of $6 \mathrm{~m}$. Net strings were each equipped with 3 equally spaced alarms of the following types: PICE, Lien (Lien \& Hood 1994) or Dukane (NetMark 1000), while 3 net strings served as controls (no alarms).

Lien (Lien \& Hood 1994, Lien et al. 1995) pingers generate 76 to 77 sounds $\min ^{-1}$ at $115 \mathrm{~dB}$. The base frequency is $2.7 \mathrm{kHz}$ with harmonics of up to $19 \mathrm{kHz}$. Dukane pingers (Net Mark 1000) generate a broad band frequency signal of $10 \mathrm{kHz}$ with individual pulses lasting $300 \mathrm{~ms}$. Pulses are repeated every $4 \mathrm{~s}$ with a source level of $130 \mathrm{~dB}$. Technical specifications of the PICE pinger are given above.

\section{RESULTS}

\section{Theodolite-tracking of harbor porpoises}

During the first part of the study, prior to deployment of the acoustic alarm, we recorded 2323 positions of 172 harbor porpoise groups. Maximum group size was 9 individuals and single harbor porpoises were also seen. Median group size was 2 animals. As shown in Fig. 1A, swimming tracks of the porpoises frequently crossed the position of the float line. Porpoise distance distribution from the mid-point of the float line (Fig. 2A) showed a median of $150 \mathrm{~m}$ (range 4 to $987 \mathrm{~m}$ ). Harbor porpoise activity during that period was reflected by a the float line. Porpoise distance from the mid-point of the float line (Fig. 2B) was distributed around a median of $530 \mathrm{~m}$ (range 130 to $1140 \mathrm{~m}$ ). This corresponds closely to the audible range of the acoustic alarm (Table 1). The mean closest approach distance of harbor porpoise groups to the pinger was $414 \mathrm{~m}$ (median $364 \mathrm{~m}$, range 130 to $930 \mathrm{~m}, \mathrm{n}=58$ approaches). Because median click number $\mathrm{h}^{-1}$ was $<0.1$ (range 0 to $103, \mathrm{n}=97 \mathrm{~h}$ of recordings), we assume that during pinger operation porpoise clicks occurred rarely within detection range of the click detector. During pinger operation, harbor porpoises swam at median speeds of $0.48 \mathrm{~m} \mathrm{~s}^{-1}$ (range 0 to $4.6 \mathrm{~m} \mathrm{~s}^{-1}, \mathrm{n}=936$ ).

After removal of the acoustic deterrent, porpoises returned to the area of the experimental net (Fig. 1C). We recorded a total of 303 positions from 22 groups ( 1 to 4 porpoises group ${ }^{-1}$, median $=2$ ) within the short time ( $7 \mathrm{~h}$ of observation over $2 \mathrm{~d}$ ) available before termination of the study. Similar to the spatial distribution of the animals prior to pinger use, surfacings were recorded within a median distance of $152 \mathrm{~m}$ from the mid-point of the float line (range 8 to 908 m; Fig. 2C). Click recordings showed that harbor porpoises again frequented the area throughout the day (median of 27 clicks $h^{-1}$, range 0 to $353, n=43$ ), although their density was reduced compared to the first part of the study. Between positional fixes, harbor porpoises swam at median speeds of $0.53 \mathrm{~m} \mathrm{~s}^{-1}$ (range 0 to $5.3 \mathrm{~m} \mathrm{~s}^{-1}$, $\mathrm{n}=283$ ).

Statistical comparison (Kruskal-Wallis test) showed that harbor porpoise distance distribution from the net significantly differed during the 3 phases of the observations $(p<0.001)$. The distribution of the animals during operation of the acoustic alarm was significantly different from their distribution before and after pinger use (Kolmogorov-Smirnov test, $\mathrm{p}<0.001$ ). Distribution of harbor porpoises during both controls (Fig. 1A,C), however, were similar ( $p>0.05)$. Statistical comparison of click recordings confirmed these results at the same significance levels. Comparison of swimming speeds during the 3 phases of the experiment (KolmogorovSmirnov test) showed that speed differences were not statistically significant $(p>0.05)$. 


\section{Test of pingers in the herring fishery}

The results of our tests conducted in commercial herring fisheries (25407 fish caught) in the Baltic Sea around the island of Rügen, Germany, yielded mean capture rates of nets equipped with Lien pingers of 6.2 herring $\mathrm{m}^{-1}$ ( $\mathrm{SD}=2.6, \mathrm{n}=40$ nets) as opposed to Dukane (4.2 herring $\mathrm{m}^{-1}, \mathrm{SD}=2.1, \mathrm{n}=32$ ), PICE (3.9 herring $\mathrm{m}^{-1}, \mathrm{SD}=2.0, \mathrm{n}=36$ ) or control nets (4.3 herring $\mathrm{m}^{-1}, \mathrm{SD}=2.4, \mathrm{n}=103$ ). Statistical comparison of these results showed that the Lien pinger seems to attract herring: capture rates of nets with Lien pingers were significantly higher (Kolmogorov-Smirnov test, $p=0.003$ ) than those of the other pinger-equipped nets or those of the unequipped control nets.

\section{DISCUSSION}

Our data show that the single PICE pinger created a large exclusion zone, with no animal approaching the float line closer than $130 \mathrm{~m}$. Kraus (1999) suggested several mechanisms which could explain this effect: (1) Startling. Harbor porpoises might become startled by the pingers and flee when hearing the sound. However, we compared individual speeds of groups observed before, during and after pinger use and could not find any differences. (2) Alerting. Harbor porpoises might become alerted upon hearing the alarm, interrogate their surroundings intensively with their biosonar, and consequently become aware of the net. This assumption could not be confirmed since the animals were too far from the floatline for investigation via their biosonar (Au 1993, Koschinski \& Culik 1997) and consequently the click detector hardly recorded any clicks during alarm operation. (3) Prey redistribution. Harbor porpoises might avoid the ensonified area because of a lack of prey (Kraus et al. 1997). Because the auditory capabilities of clupeid fishes indicate that they are able to hear ultrasonic frequencies (Mann et al. 1997), we tested in a separate experiment whether the reaction of harbor porpoises could be mediated by the avoidance reaction of their prey. However, our data show that the 3 types of pingers (PICE, Lien and Dukane), albeit working at different sound and repetition frequencies, did not reduce herring capture success in a commercial fishery. We conclude that the reaction of harbor porpoises to acoustic alarms can therefore not be mediated by prey redistribution.

This leaves one further explanation for the observed effect of PICE pingers on harbor porpoises: the 'annoying hypothesis' formulated by Kraus (1999). He suggested that porpoises might avoid pingers 'the way humans avoid static or unpleasant noise'. However, he continues, 'given the high tolerance of urban humans
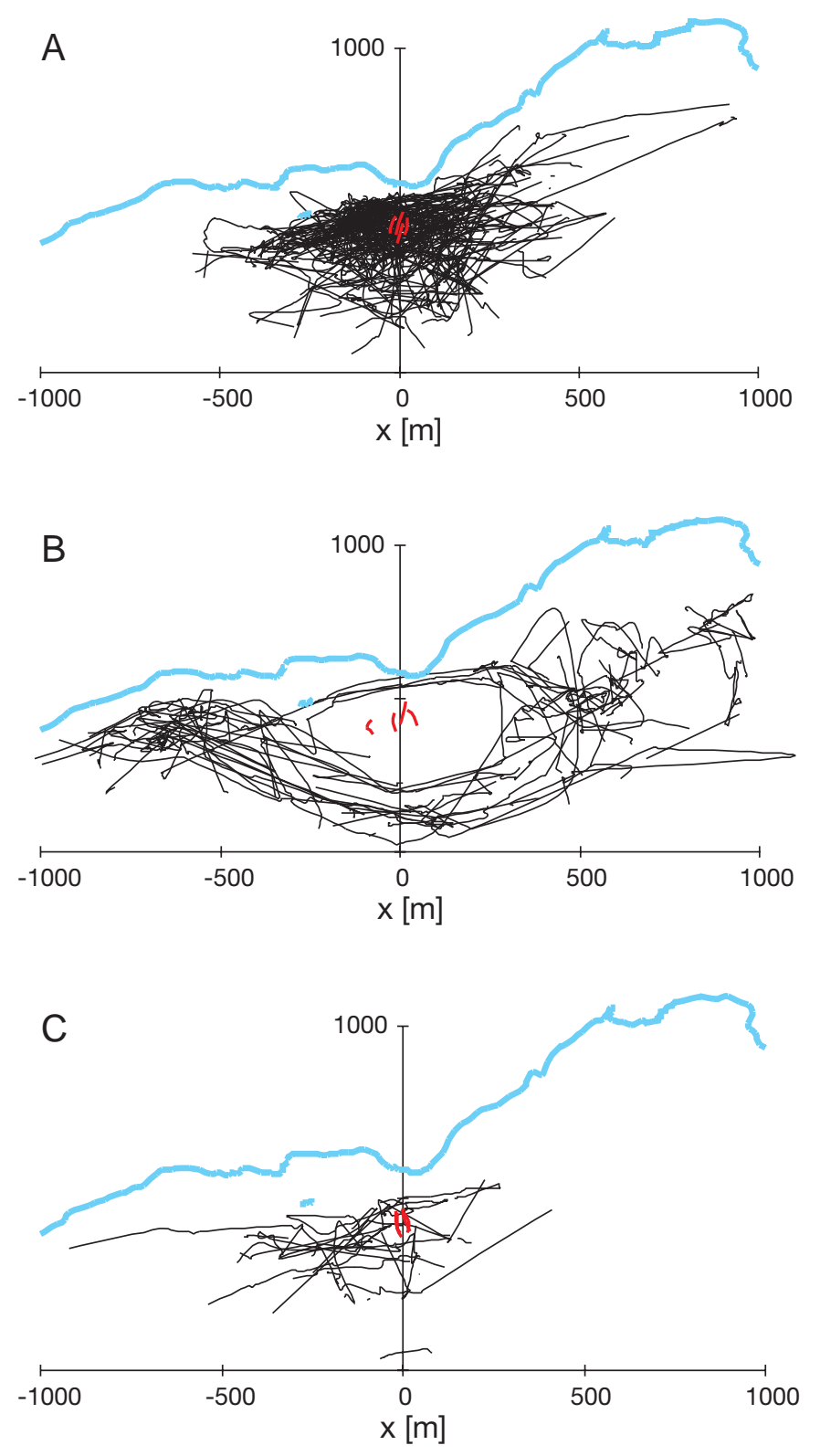

Fig. 1. Harbor porpoise Phocoena phocoena movements in Fortune Channel, Clayoquot Sound, Vancouver Island (black lines show tracks of porpoise groups). (A) Control, (B) during the operation of an acoustic alarm placed in the middle of the float-line, (C) after removal of the alarm. The coast is shown in blue, the float line is marked in red. Due to tide movements, the position of the float line varied from day to day. The theodolite was positioned at the origin of the $x$ - and $y$-axes

to traffic and construction noise, it is likely that if pingers are annoying, there is a good argument for believing they will lose their effectiveness over time as animals become habituated to the sounds' (Kraus 1999). Although we did not observe any habituation effect during the short period of pinger operation (5 d), its emergence is likely: harbor porpoises moved far 

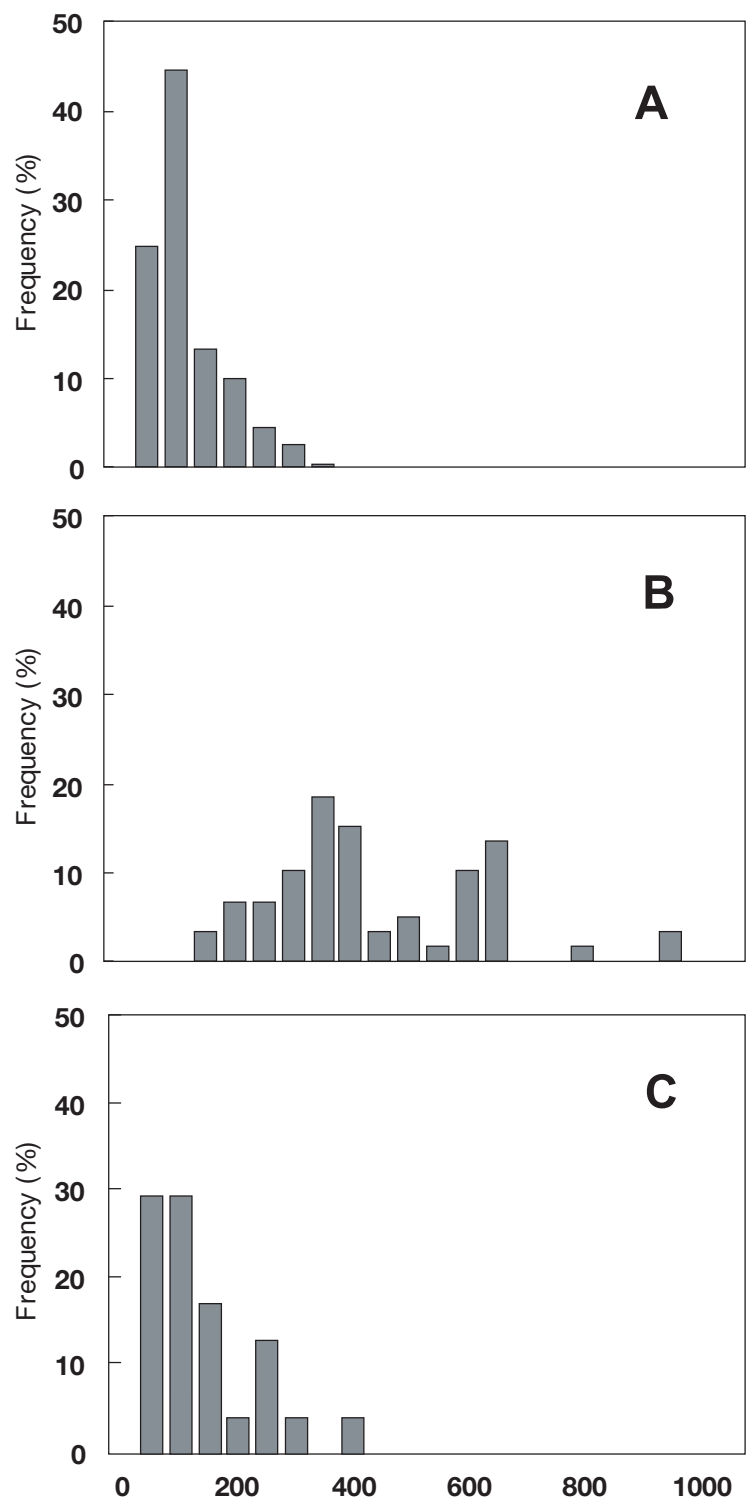

Fig. 2. Distance distribution of harbor porpoise Phocoena phocoena groups from the mid-point of the float line (position of the PICE pinger). (A) Control prior to the experiment, (B) during pinger operation, $(\mathrm{C})$ after operation of the acoustic alarm

enough away on average to reduce the high frequency components of pinger sounds to a value marginally above their hearing threshold (Andersen 1970). This 'habituation hypothesis' will be further investigated.

The practical deployment of pingers in commercial fisheries involves very difficult compliance monitoring, but the confirmation of the 'annoying mechanism' of pinger effect adds yet another problem - habitat exclusion. Lien pingers (115 dB) previously tested in Fortune Channel, Canada (Koschinski \& Culik 1997), forced harbor porpoises to remain outside a mean closest approach distance of $133 \mathrm{~m}$ around the pinger. One
PICE alarm results in a significantly larger displacement of the animals (414 m mean closest approach distance). The difference is significant $\left(\chi^{2}\right.$-test, $\left.\mathrm{p}<0.001\right)$. Larger exclusion zones may be considered ideal to reduce by-catch risks. However, because of the extensive deployment of various forms of gillnets along the coasts of the northern hemisphere (fishery authorities in Kiel, Germany, e.g., estimate that $1000 \mathrm{~km}$ of gillnets are set at any given time along $100 \mathrm{~km}$ of coast line in the German Baltic Sea), widespread pinger deployment would effectively exclude harbor porpoises from bays, fjords and other areas. Aversive behaviour to pinger sounds would force the animals into sub-optimal areas where increased levels of competition for food might reduce their fitness. Non-alarmed nets in such areas might pose further risks.

In addition to causing increased levels of acoustic pollution, acoustic alarms might thus be detrimental to harbor porpoise conservation via habitat exclusion and habituation. Therefore, we advocate that the use of acoustic alarms in gillnets should not substitute, but complement other measures, such as localized fishing closures. This would reduce by-catch and potentially protect important forage fish in areas of porpoise abundance.

Acknowledgements. We would like to thank Klaus Scholz, Fockbeck, who provided the PICE pingers, John Lien, who provided his Lien pingers, and Dukane Inc. for providing Dukane pingers. Geodimeter Canada kindly lent us the theodolite and analysing software. Dr Christine Gerlach, Mönkeberg, kindly provided an electronic bat detector to determine whether the PICE pinger was functional. Mr Kathe and Dipl.-Ing. C. Jansen from the WTD 71, Bundeswehr Plön, determined pinger source levels. Rick and Maggy Charles, Tofino, BC, Canada helped in every possible way and $\mathrm{Dr}$ Louise Lovekin, Tofino, kindly let us use her guest house and dock. We gratefully acknowledge the comments of Lee Miller, Jonas Teilmann, Geneviève Desportes, Finn Larsen and KarlHermann Kock on an earlier version of the manuscript. This work was made possible through grant CAN $97 / 002$ by the International Bureau of the Bundesministerium für Bildung und Forschung, Bonn, and by the Ministerium für Ländliche Räume, Landwirtschaft, Ernährung und Tourismus des Landes Schleswig-Holstein. The research permit for field work in Canada was issued by the Department of Fisheries and Oceans, Nanaimo, BC, Canada.

\section{LITERATURE CITED}

Andersen S (1970) Auditory sensitivity of the Harbor porpoise (Phocoena phocoena). In: Pilleri G (ed) Investigations on cetacea, Vol II. Hirnanatomisches Institut, Bern, p 255-259 $\mathrm{Au}, \mathrm{WWL}$ (1993) The sonar of dolphins. Springer Verlag, New York

Kastelein RA, Au WWL, de Haan D (2000a) Detection distances of bottom-set gillnets by harbour porpoises (Phocoena phocoena) and bottlenose dolphins (Tursiops truncatus). Mar Environ Res 49:359-375 
Kastelein RA, Rippe HT, Vaughan N, Schooneman NM, Verboom WC, de Haan D (2000b) The effects of acoustic alarms on the behaviour of harbor porpoises (Phocoena phocoena) in a floating pen. Mar Mamm Sci 16:46-64

Koschinski S, Culik BM (1997) Deterring harbor porpoises (Phocoena phocoena) from gillnets: observed reactions to passive reflectors and pingers. Rep Int Whaling Comm 47: $659-668$

Kraus SD (1999) The once and future ping: challenges for the use of acoustic deterrents in fisheries. Mar Technol Soc J 33:90-93

Kraus SD, Read AJ, Solow A, Baldwin K, Spradlin S, Anderson E, Williamson J (1997) Acoustic alarms reduce porpoise mortality. Nature 388:525

Lien J, Hood C (1994) An investigation of acoustic devices to prevent harbor porpoise by-catch in groundfish gillnets, and recommendations from fishermen in the Bay of Fundy for future by-catch mitigation. Report to the Department of Fisheries and Aquaculture, Fredericton, New Brunswick and the Department of Fisheries and Oceans, Halifax, Nova Scotia

Editorial responsibility: Otto Kinne (Editor),

Oldendorf/Luhe, Germany
Lien J, Hood C, Pittman D, Ruel P, Borggaard D, Chisholm C, Wiesner L, Mahon T, Mitchell D (1995) Field tests of acoustic devices on groundfish gillnets: assessment of effectiveness in reducing harbor-porpoise by-catch. In: Kastelein RA, Thomas JA, Nachtigall PE (eds) Sensory systems of aqautic mammals. De Spil Publisher, Woerden, p 1-22

Mann DA, Lu Z, Popper AN (1997) A clupeid fish can detect ultrasound. Nature 389:341

Rochas-Bracho L, Taylor BL (1999) Risk factors affecting the vaquita (Phocoena sinus). Mar Mamm Sci 15:974-989

Tregenza NJC, Berrow S, Leaper R, Hammond PS (1997) Harbor porpoise, Phocoena phocoena L., by-catch in set gill nets in the Celtic Sea. ICES J Mar Sci 54:896-904

Trippel EA, Strojg MB, Terhune JM, Conway JD (1999) Mitigation of harbor porpoise (Phocoena phocoena) by-catch in the gillnet fishery in the lower Bay of Fundy. Can J Fish Aquat Sci 56:113-123

Vinther M (1999) Bycatches of harbor porpoises (Phocoena phocoena L.) in Danish set-net fisheries. J Cetacean Res Manage 1(2):123-135

Submitted: April 27, 2000; Accepted: July 25, 2000

Proofs received from author(s): January 15, 2001 